\title{
A Review on Fossil Findings of Central Iran's Permo-Triassic Deposits
}

\author{
Hamideh Noroozpour*, Mostafa Yousefi Rad \\ Faculty of Sciences, Department of Geology, Payame Noor University, Tehran, Iran \\ Email: ${ }^{*}$ Hamidehnoroozpour@yahoo.com
}

Received 20 March 2015; accepted 5 June 2015; published 8 June 2015

Copyright (C) 2015 by authors and Scientific Research Publishing Inc.

This work is licensed under the Creative Commons Attribution International License (CC BY). http://creativecommons.org/licenses/by/4.0/

(c) (i) Open Access

\begin{abstract}
In this research, a review was done on Permo-Triassic deposits in Central Iran including Abadeh, Hambast, and Elika formations. Following an overview about the circumstances of Central Iran Basin during Permotriassic time interval, the respective formations are introduced, and then, history of paleontology studies on these deposits will be depicted. Through analysis and comparison of previous studies, the following ages were estimated for the aforementioned formations: Early Dzhulfian for Abadeh Formation, Late Dzhulfian-Dorashamian for Hambast Formation, and Early Triassic (Scythian) for Elika Formation. Also, Permotriassic boundary in Central Iran is continuous, bearing the proposed sedimentation and fossil content. It is noteworthy that due to volcanic events at the boundary of these deposits in Central Iran, one might infer that occurrence of the aforementioned activities has been among the major causes of the respective extinction.
\end{abstract}

\section{Keywords}

\section{Abadeh, Central Iran, Hambast, Permotriassic}

\section{Introduction}

It is highly significant to study deposits of Permo-Triassic boundary because this boundary indicates many events in the geological history and transition from Paleozoic into Mesozoic. The respective boundary is accompanied with depth variations all around the world, during which atmospheric and climatic conditions, and consequently, ecosystem of the earth undergoes great transformations [1]. In fact, an extremely massive extinction dominated extensive parts of the earth at the end of Permian, known as one of the greatest extinction phenomena in the history of the planet [2].

Unfortunately, Permo-Triassic boundary deposits that are capable of reflecting geological record of this time

\footnotetext{
${ }^{*}$ Corresponding author.
} 
interval have been restricted to few locations of the globe, such as Abadeh, Dzhulfa, and South China regions [1]. In Iran also, Permo-Triassic deposits are observed continuously and together with sedimentation within a geosyncline during Late Permian resulting from gradual closure of Paleo-Tethys [3]. This geosyncline has a northwestern-south-eastern trend and is parallel with the main Zagros Fault, extending from Dzhulfa Region in northwestern area of Iran up to Hambast Mountain Range in Central Iran Late Permian deposits in Iran which are recognized as Abadeh and Hambast Formations [4] and Early Triassic deposits are equivalent to Elika Formation:

- Abadeh Formation with the age of Early Dzhulfian and thickness of 334 meters comprises units 4 and 5 in Taraz's study [4]. This formation represents that carbonate-terrigenous deposits have a continuous boundary with deposits of Hambast Formation. It must be noted that the respective formation is chronologically equivalent to Nesen Formation in Alborz Region [5] [6].

- Hambast Formation with Early Dzhulfian-Dorashamian age and thickness of 36.5 meters in the type section is representative of carbonate deposits with terrigenous interbeds. Deposits of this formation that incorporate units 6 and 7 of the study are conducted by Taraz [4]. In most regions, the respective formation has continuous boundary with deposits of Elika formation (Early Triassic).

- Deposits of Elika Formation with the age of Early Triassic contain carbonate sediments with terrigenousinterbeds such as dark shales. These deposits were designated by Shen [7], and Liu [8]. As Elika Formation (as Shahreza Formation in the stratigraphic section of Shahreza City).

The main question of the present study is about continuity or discontinuity of the deposits at Permian-Triassic boundary in Central Iran. To answer this question, the previous paleontological studies must be reviewed.

\section{Previous Studies}

Numerous studies have been conducted on microfossils of Permo-Triassic deposits in Central Iran as of today. These studies and results are briefly presented below:

- Having studied the Upper Permian-Lower Triassic sequence in Abadeh Region [9] thoroughly analyzed the ammonoidea in the region of interest.

- Iranian-Japanese Research Group [10] studied Permo-Triassic deposits of Abadeh Region and proposed the boundary of deposits as a paraconformity.

- Which agrees with our finding here. The existence of this paraconformity in the studied regions are recognizable and also confirmed .

- Yazdi \& Shirani [11] studied and correlated the Permo-Triassic deposits in stratigraphic sections of Hambast, Shahreza, and Chah-Riseh. In their study, Permian deposits were assigned to Early Dzhulfian-Late Dorashamian based on stratigraphic distribution of conodonts, and, the initial Triassic sediments were also attributed to Early Triassic (Scythian) due to presence of Claria.

- Kouzer [12]-[14] studied taxonomy of Permo-Triassic conodonts of Shahreza and Abadeh (Central Iran).

- Through studying conodonts and macrofossils of Permo-Triassic deposits in northeast of Abadeh, Ghaedi [15] proposed that the extinction phenomenon has occurred at the beginning of Triassic and not the end of Permian at least in this region that is aproximately similar to the age of extinction, recognized in the regions of interest.

\section{Discussion}

In this research, for the first time palynomorphs of Permo-Triassic deposits in Shorjestan Region in northwestern part of Abadeh City were studied. They attributed the deposits of Hambast Formation to Late Permian and the deposits of Elika Formation to Early Triassic. They proposed the boundary of the respective deposits as a continuous transition

According to our findings, it can be presumed that Permo-Triassic deposits in some parts of Central Iran have been formed continuously and transitionally at the end of Permian and simultaneously with gradual closure of Paleo-Tethys.

In Iran the gradual boundary for Permo-Triassic deposits limit to a few outcrops only that one of them is Central Iran zone. Studies done by researchers, e.g., Kouzer indicate that in Dzhulfa to Oman, thickness of this gradual boundary is different. On the other hand, an unconformity, although very subtle \& fine has been distinguished. As an example at the same time Paleo-Tethys in Zagros basin was closed completely and a sharp un- 
conformity between Dalan and Kangan formations can be recognized.

Thrombolites identified in field geology observations are strong evidences to confirm existence of this unconformity in mentioned boundary in Zagros zone. While in Central-Iran zone, facies similar to Dzhulfa \& Araz have been seen but long distance on ground and differences in lithology in this area shows that age \& facies of Permo-Triassic boundary in Central-Iran may differ from those in Dzhulfa \& Araz.

As said above and according to Kouzer [12]-[14], Permo-Triassic boundary especially Dorashamian stage varies from 17 meters in Dzhulfa to 6 meters in Central Iran in thickness.

This research demonstrates that deposits of Abadeh Formation date back to Early Dzhulfian and those of Hambast Formation has the age of Late Dzhulfian-Dorashamian, and finally, deposits of Triassic also belong to the first Triassic stage (Scythian). With regard to the field evidences offered, it can be inferred that boundary of Permo-Triassic deposits is continuous. Furthermore, taking into account the evidences presented in studies, it might be supposed that events like volcanic activities have been able to cause occurrence of such a massive and extensive extinction at Permo-Triassic boundary; however, many of fossil groups have survived the aforementioned boundary [16]. It is noteworthy that based on the palynomorphs reported in the study carried out by us, one might conclude that deposits of Permo-Triassic boundary have been settled in a very shallow marine environment.

\section{Conclusions}

1) Based on the studies on palynomorphs, the following ages are assigned to the deposits of the respective formations: Early Dzhulfian for Abadeh Formation, Late Dzhulfian-Dorashamian for Hambast Formation and Scythian for Elika Formation.

2) Boundary of Permo-Triassic deposits is continuous and transitional in majority of Central Iran regions.

3) Depositional environment of the respective sediments has been a very shallow marine and near-coastal environment.

4) Factors such as volcanic activities have led to the mentioned extinction in Central Iran.

5) With due attention to the nature \& quiddity of Geology as a science with lots of variety and changes from place to place even in very short distances it is not so far to reach different results by different researchers who have applied different materials and methods such as fossils, minerals, rocks, sediments and etc. They are all respected and target of this study was to just have a deeper and more precise investigations and studies of Permo-Triassic boundary in Paleo-Tethys trough.

It is strongly recommended to hold more expanded, supervised and well-organized studies on Permo-Triassic boundary to reject or confirm any of previous results or to solve problems and clear any probable ambiguity about it.

\section{References}

[1] Sweet, W.C., Yang, Z.Y., Dickins, J.M. and Yin, H.F. (1992) Permo-Triassic Events in the Eastern Tethys-An Overview. In: Sweet, W.C., Yang, Z.Y., Dickins, J.M. and Yin, H.F., Eds., Permo-Triassic Events in the Eastern Tethys, Cambridge University Press, Cambridge, 1-18. http://dx.doi.org/10.1017/CBO9780511529498.002

[2] Wignall, P.B. (2005) Permian. In: Selly, R., Cocks, L.R.M. and Plimer, I.R., Eds., Encyclopedia of Geology, Elsevier Ltd., 214-218. http://dx.doi.org/10.1016/B0-12-369396-9/00050-2

[3] Stampfli, G.M. and Borel, G.D. (2002) A Plate Tectonic Model for the Paleozoic and Mesozoic Constrained by Dynamic Plate Boundaries and Restored Synthetic Oceanic Isochrones. Earth and Planetary Science Letters, 196, 17-33. http://dx.doi.org/10.1016/S0012-821X(01)00588-X

[4] Taraz, H. (1974) Geology of the Surmaq-Deh Bid Area, Abadeh Region, Central Iran. Geological Survey of Iran, Report No. 37, 1-148.

[5] Partoazar, H. (1995) Permian System in Iran. Geological Society of Iran, 22, 340. (In Persian)

[6] Partoazar, H. (2002) Permian-Triassic Boundary Conodonts from Dzhulfa-Abadeh Belt along Northwest and Central Iran. Permophiles, 41, 34-40.

[7] Shen, S.Z., Gorgij, M.N., Wang, W., Zhang, Y.C., Khamar, H.R. and Tanatabaei, S.H. (2009) Report of Field Trip of the Permian Stratigraphy in Central and Eastern Iran. Permophiles, 53, 2-5.

[8] Liu, X.C., Wang, W., Shen, S.Z., Gorgij, M.N., Ye, F.C., Zhang, Y.C., Furuyama, S., Kano, A. and Chen, X.Z. (2012) Late Guadlupian to Lopingian (Permian) Carbon and Strontium Isotopic Chemostratigraphy in the Abadeh Section, 
Central Iran. Gonwana Research, 11.

[9] Bando, Y. (1979) Upper Permian and Lower Triassic Ammonoids from Abadeh, Central Iran. Vol. 29, Memoirs of the Faculty of Agriculture, Kagawa University, Takamatsu, 103-138.

[10] Iranian-Japanese Research Group (1981) The Permian and the Lower Triassic Systems in Abadeh Region, Central Iran. Vol. 47, Memoirs of the Faculty of Science, Kyoto University, Takamatsu, 66-133.

[11] Yazdi, M. and Shirani, M. (2002) First Research on Marine and Nonmarine Sedimentology Sequences and Micropaleontologic Significance across Permian-Triassic Boundary in Iran (Isfahan \& Abadeh). Journal of China University of Geosciences, 13, 172-176.

[12] Kouzer, H.W. (2004) Pelagic Uppermost Permian and the Permian-Triassic Boundary Conodonts of Iran, Part I: Taxonomy. Hallesches Jahrbuch für Geowissenschaften, 18, 39-68.

[13] Kouzer, H.W. (2005) Pelagic Uppermost Permian and Permian-Triassic Boundary Conodonts of Iran, Part II: Investigated Sections and Evolution of the Conodont Faunas. Hallesches Jahrbuch für Geowissenschaften, 19, 49-86.

[14] Kouzer, H.W. (2007) Biostratigraphy and Event Stratigraphy in Iran around the Permian-Triassic Boundary (PTB): Implications for the Cause of the PTB Biotic Crisis. Global and Planetary Change, 55, 155-176. http://dx.doi.org/10.1016/j.gloplacha.2006.06.011

[15] Ghaedi, M. (2009) Biostratigraphy and Lithostratigraphy of Permotriassic Boundary in Bonarizeh Section, NE of Abadeh on the Basis of Conodonts and Macrofossils. M.Sc Thesis, University of Isfahan, Isfahan, 112. (In Persian)

[16] Wang, Y.B., Tong, J.N., Wang, J.S. and Zhou, X.G. (2005) Calcimicrobialite after End-Permian Mass Extinction in South China and Its Palaeoenvironmental Significance. Chinese Science Bulletin, 50, 665-671. 